\title{
The Vietnamese entrepreneurship paradox: how can entrepreneurs thrive without political and economic freedom?
}

\author{
David B. Audretsch ${ }^{1} \cdot$ Antje Fiedler $^{2}$ (D)
}

Accepted: 22 July 2021 / Published online: 4 August 2021

(C) The Author(s), under exclusive licence to Springer Science+Business Media, LLC, part of Springer Nature 2021

\begin{abstract}
Entrepreneurship and democracy are often considered complementary, but recent evidence points to a paradox that entrepreneurial activities have increased in undemocratic contexts. Exploring economic and political freedoms, this paper investigates the development of entrepreneurship in Vietnam, an economy characterised by low economic and very low political freedoms. It suggests changes in economic freedom over time influence opportunity perceptions and activities more than absolute levels. We identify key aspects of how culture and institutions have changed, which have been conducive to entrepreneurship. Overall, we show how even small increases in economic freedom stimulate entrepreneurship, even in the absence of political freedom.
\end{abstract}

Keywords Economic freedom · Political freedom · Democracy · Entrepreneurship · Vietnam

JEL Classification O430 Institutions and Growth · M130 New Firms · Startups $\cdot$ P00 General

\section{Introduction}

Democracy is often considered an important condition for entrepreneurship, endowing the political and economic freedoms that enable entrepreneurial endeavours. Empirical research links economic and political freedoms to entrepreneurship (e.g., Clark \& Lee, 2006; Bennett, 2021; Herrera-Echeverri, Haar, and Estévez-Bretón, 2014; Audretsch \& Moog, 2020). Poignent examples highlight the suppression of both democratic values and

Antje Fiedler

a.fiedler@auckland.ac.nz

David B. Audretsch

daudrets@indiana.edu

1 Institute for Development Strategies, Indiana University, Bloomington, IN, USA

2 Graduate School of Management, University of Auckland, Private Bag 92019, Auckland,

New Zealand 
freedoms and entrepreneurship during National Socialism in 1930s Germany, the American civil war, and the recent Covid-19 pandemic (Audretsch \& Moog, 2020). While there may be compelling contexts linking economic and political freedoms to entrepreneurship, there are also glaring anomalies. Democratized and economically relatively free countries, such as the US, struggle to lift entrepreneurship. By contrast are countries exhibiting a paucity of democracy and fickle economic freedom, yet robust levels of entrepreneurship, such as China (Bradley \& Klein, 2006). Private Chinese entrepreneurs apparently compensate for the lack of economic freedom by raising resources in novel ways (Tsai, 2005, 2007).

If democracy, and the freedoms it brings, are nevertheless important, then how can we reconcile an apparent paradox: rising entrepreneurial activities in countries and contexts characterized by a paucity of democracy and freedom, such as China and Vietnam? While economic and political freedom remain restricted in many national contexts, the World Bank Group (2020b) describes Vietnam's economic development since around 1990 as remarkable, putting it among "the most dynamic emerging countries" in East Asia. Vietnam has been celebrated as "the other Asian Tiger" besides China and India by The Economist (2016) for its "past success and future promise", boasting the "second-fastest growth rate per person since 1990". Symbolizing this, in 2014, VNG, a privately owned Vietnamese gaming company, became Vietnam's first "unicorn" (valued at over \$1bil$\operatorname{lion}^{1}$ ), and one of only two in Southeast Asia. The Global Innovation Index (2019) (GII) has, since 2010, classed Vietnam as an "innovation achiever" (outperforming its economic development level) and, in 2019. ranked it 42/129 economies for innovation performance and among the Top 3 innovators among lower-middle income economies. ${ }^{2}$ In particular, according to the BBC, over 3,000 technology start-ups "mak[e] it the third-largest tech start-up ecosystem in Asia". 3

The purpose of this paper is to resolve the paradox posed by Vietnam-how and why a socialist state, like China, is able to defy a growing body of literature concluding that democracy and economic freedom are pre-requisites for fostering entrepreneurship. Resolving this paradox is not only important to the entrepreneurship literature, because it challenges or at least calls for rethinking what has been widely accepted as an unequivocal truism, but also because it sheds new and novel light on how and why diverse and heterogeneous institutional contexts can be conducive to entrepreneurship. To date, knowledge on how entrepreneurship has evolved in emerging economies, such as Vietnam, is scarce (Bruton, Sutter and Lenz, 2021). We focus on Vietnam because it offers a compelling case of how entrepreneurship can flourish in a context with limited economic and political freedoms. In Vietnam, innovation in certain sectors has flourished despite a paucity of government support (Gasparin \& Quinn, 2021) and democracy. Therefore, Vietnam can provide new insights into the relationship between democracy and entrepreneurship.

To address the entrepreneurship paradox posed by Vietnam, this paper draws on strands from several different academic disciplines. In particular, the literature in

\footnotetext{
1 https:/e.vnexpress.net/news/business/companies/digital-payment-firm-vietnam-s-second-startup-unicorn4199895.html.

2 Vietnam scores 63/129 for innovation inputs, which combines scores of five pillars, namely Institutions, Human capital and research, Infrastructure, Market sophistication, and Business sophistication, and 37/129 for innovation outputs, which includes Knowledge \& technology outputs and Creative outputs.

3 BBC (2018). Vietnam's tech innovation renaissance. 01 March 2018. https://www.bbc.com/news/av/busin ess-43196792/vietnam-s-tech-innovation-renaissance.
} 
Political Science has provided compelling empirical evidence distinguishing between economic and political freedoms, as well as their effects on entrepreneurship and economic growth; however, the mechanisms are far from settled. While some studies indicate economic freedom impacts economic performance more (e.g. Li \& Xu, 2007), others find that economic freedom may precede political freedom, and that economic freedom, can subsequently yield benefits accruing from political freedom as a country ascends the arc of development (Xu \& Li, 2008), suggesting that different types of freedoms may most matter at different development stages. Friedman (1962) emphasizes economic freedom as an "indispensable means" towards political freedom (p. 52). In short, the triangular relationship between economic freedom, political freedom and entrepreneurship is complex and fraught with seeming contradictions and ambiguities. A key and novel contribution of this paper is to resolve these apparent contradictions and ambiguities by showing how and why the institutional context matters in shaping the exact relationships among economic freedom, political freedom and entrepreneurship.

In particular, this paper resolves the entrepreneurship paradox posed by Vietnam by explaining how and why entrepreneurship is able to thrive in an institutional context with a paucity of both economic and political freedom. By examining institutions specific to Vietnam and how they evolve over the development arc, we find that high absolute levels of economic and political freedom are not a prima facia requisite for robust entrepreneurial activities. In fact, even small and incremental relative advances in economic and political freedoms can boost entrepreneurship. Changes in the degree of political and economic freedom over time apparently matter for entrepreneurship.

The observed robustness and resilience of opportunity-driven entrepreneurship is attributable to three underlying forces specific to the context of Vietnam. The first rests within the optimism inherent in (nascent) entrepreneurs. The second, while bureaucratic rigidities impeding dynamism in some key industries in the compressed-development state, low level of regulation in adjacent industries encourage entrepreneurship. The previous institutional regime was characterized by supressing entrepreneurship through stringent bureaucratic regulations and restrictive policies. The third underlying force attributable for a flourishing entrepreneurial landscape in Vietnam is that importation an adoption of developed market Silicon Valley style templates fuelled by the return of expatriates, which serves to fill the institutional void in this otherwise emerging market by emulating the Silicon Valley ecosystem model and values.

The findings of this paper challenge the unqualified blanket conclusions of the extant literature that without democracy and economic freedom, there is little hope for entrepreneurship. Instead, this paper suggests a better way to view the links between democracy and entrepreneurship is that, depending upon the development context, changes in democracy and economic freedom may be at least as important for entrepreneurship as are the levels. When it comes to entrepreneurship, democracy and economic freedom matter relative to a country's past and expected future, and not necessarily in absolute terms. As we find in this paper, even minor and incremental advances of economic freedom in the context of Vietnam can significantly enhance entrepreneurial activity. It may be that the perceived increases in economic freedom ignites optimism and aspiration in (nascent) entrepreneurs.

The next section of the paper analyses how and why political and economic freedoms matter for entrepreneurship. In the third section the specific context of Vietnam and its evolving freedoms and of entrepreneurship and innovation are examined. This enables an identification of three salient underlying forces shaping entrepreneurship, even with a paucity of democracy. The final section provides a summary and conclusion. In particular, 
this paper finds that, in sharp contrast to the conclusions prevalent throughout the existing literature, entrepreneurship can thrive even where political and economic freedoms are not pervasive.

\section{Why are political and economic freedoms important for entrepreneurship?}

A consensus concludes that economic and political freedom benefit entrepreneurial activities (Berggren, 2003). Similarly, economic and political freedoms are considered to coexist for compelling reasons. Less understood are the mechanisms linking various aspects of freedom to entrepreneurship. Studies indicate that different aspects of freedoms matter more, less or not at all, depending upon the type of entrepreneurship (Bjørnskov \& Foss, 2008). For the purpose of our study, we follow Audretsch and Keilbach (2004) and operationalize the concept of entrepreneurship as the activities and actions by agents with the purpose to create new firms. While direct measures are unavailable, a link exists between entrepreneurial activities and formal venture creation and economic growth, making it a key proxy for entrepreneurship. In the following the effects of economic and political freedom on entrepreneurship are discussed.

First, economic freedom, defined as "freedom to engage in economic activity without undue restrictions or subsidies", is a significant aspect of the institutional environment impacting entrepreneurial activities (Bradley \& Klein, 2016, p. 211). For example, Saunoris and Sajny (2017) maintain that economic freedom promotes formal entrepreneurship instead of "underground enterprises" (p. 311). McMullen, Bagby and Palich (2008) dissect economic freedom indicators and entrepreneurial activities. They distinguish among fiscal freedom, which characterizes the tax burden set by the government, monetary freedom, which reflects polices affecting price controls and inflation, and labor freedom, which involves restrictions imposed on wages. They find that some specific types of economic freedom are positively associated with "necessity entrepreneurship", and are an alternative to the "want of employment". Necessity entrepreneurs typically value lower transaction costs and less uncertainty, not just higher expected returns. However, to encourage innovative entrepreneurial activities, or "Opportunity-driven entrepreneurship" (ODE), which often creates new knowledge, property rights and labor freedom mattered most. Thus, innovative entrepreneurs, being more ambitious, are more motivated by the prospects of entrepreneurial rents (McMullen et al., 2008). These studies suggest that the relationships between economic freedom and specific types of entrepreneurial activities are complex, and that measuring economic freedom in absolute or aggregated terms might obscure key differential mechanisms.

Further complicating those relationships is the entrepreneurial activity context. Gohmann, Hobbs and McCrickard, (2008) find significant inter-industry variation, suggesting that industry context matters; in some industries, such as health and legal services, economic freedom actually reduces business creation. Herrera-Echeverri et al. (2014) empirically show that access to international trade boosts entrepreneurship in the context of low income countries. By contrast, the freedom to start a business and access to investment are conducive to new business registrations in the context of emerging countries. The development stage may also matter (Kuckertz, Berger and Mpeqa, 2016); whereas in the context of emerging markets, economic freedom significantly explains necessity entrepreneurship, ODE is more complex. A paucity of economic freedoms seems to inhibit innovative 
entrepreneurial activities, especially in the context of more advanced economies (Kuckertz, Berger and Mpeqa, 2016).

Second, political freedom encompasses political rights, including the right to vote, form a political party and participate in political activities; civil liberty rights, including the rule of law, freedom of expression, religion and belief; and individual rights (Freedom House, 2020b; Hewlett, 1979). The political/economic distinction is not clear-cut (and indeed an issue is how divisible versus bound up they are). More specifically, political freedom is often deemed an antecedent to entrepreneurship because more democratic governments are believed to better protect the economic freedom of private property rights, thus encouraging investment and incentivizing entrepreneurs by letting them keep the fruits of their endeavours (Dheer, 2017). By contrast, Communist states, for instance, traditionally minimize private ownership. Political forces have sometimes resisted or crushed entrepreneurial success, so dissuading would-be entrepreneurs (Clark and Lee, 2006), as in apparently politically motivated closures of successful rural enterprises in China during crackdowns on the private sector (Huang, 2008). Thus, entrepreneurs operating amid low political freedoms may find their government arbitrarily intervening in closing or seizing their business (Audretsch \& Moog, 2020).

\section{The context of Vietnam}

\subsection{Political and economic freedom in Vietnam}

Linking political and economic freedom requires measurement. Thus, we rely on several well-known sources of data measuring political and economic freedom. In terms of economic freedom, the World Bank Group (2021) ranks Vietnam a moderate 70/190 on ease of doing business, but this hides some ambiguity, with wide variations across categories. Notably, the country rates relatively well in "getting credit"" (25/190) and "dealing with construction permits" (25/190) but languishes in "starting a business" (115/190) (The World Bank Group, 2021). Vietnam is attractive for Foreign direct investment (FDI), averaging US\$3billion, while many domestic businesses encounter severe growth constraints (The World Bank Group, 2019). Thus the business climate and regulation might deliberately promote larger and foreign companies over home-grown entrepreneurs.

The World Bank Group Vietnam Enterprise Survey compiles valuable information on business obstacles and corruption from 996 face-to-face interviews with owner and managers over November 2014-April 2016. The participants considered "access to finance" their biggest obstacle for doing business, 22\% reporting it as such in 2015 (The World Bank Group, 2020b), even though the World Bank Group (2020a) ranked Vietnam internationally $25 / 190$ in providing credit. Also, $26.1 \%$ reported bribery demands and a staggering $90.7 \%$ of firms were "expected to give gifts to public officials' to get things done' based on the enterprise survey (The World Bank Group, 2020b). Bribery appears to depend on the domain: reported by only $25 \%$ of businesses for obtaining construction permits but $57 \%$ for winning government contracts (The World Bank Group, 2015). Freedom from corruption is included as an economic freedom by the Heritage Foundation (2020a).

While these results show significant obstacles for owner-managers due to ambiguous economic freedom, evidence indicates economic freedom has improved since 1997. Figure 1 shows an overall index of economic freedom, aggregating multiple categories. While positive changes to economic freedom in Vietnam can be observed since 1997, the overall 


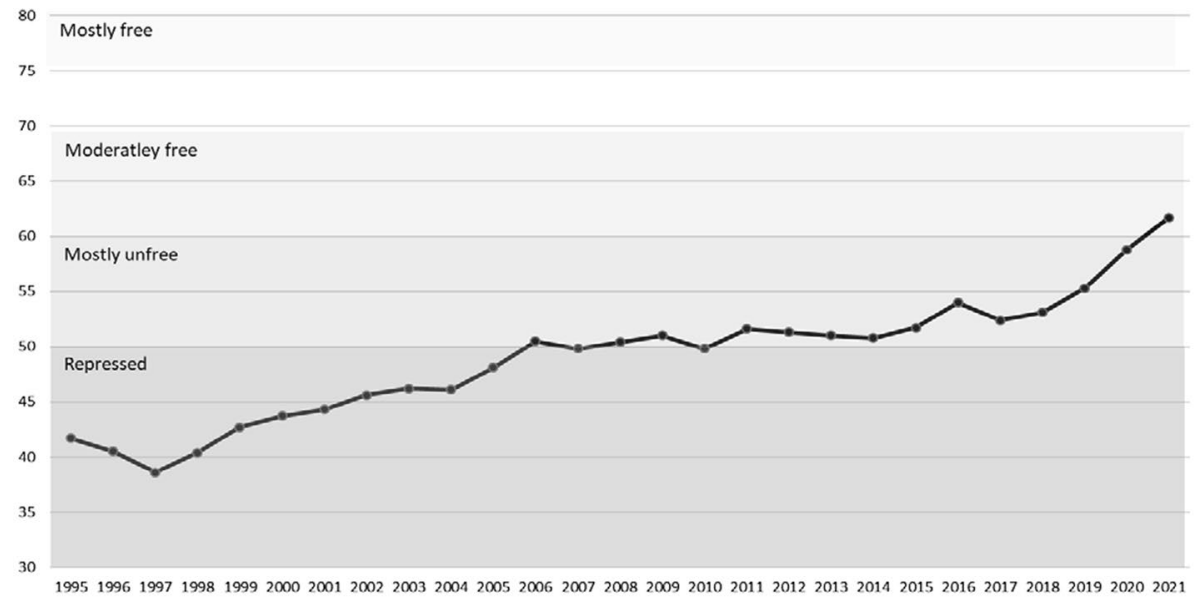

Fig. 1 Development of economic freedom in Vietnam. Source of data: https://www.heritage.org/index/ visualize?cnts=vietnam $\&$ src=country. Note: Economies are categorised into one of five categories: Below $50=$ 'Repressed'; 50-59.9= 'Mostly unfree'; 60-69.9= 'Moderately free'; 70-79.9= 'Mostly free'; 80 and above $=$ 'Free'

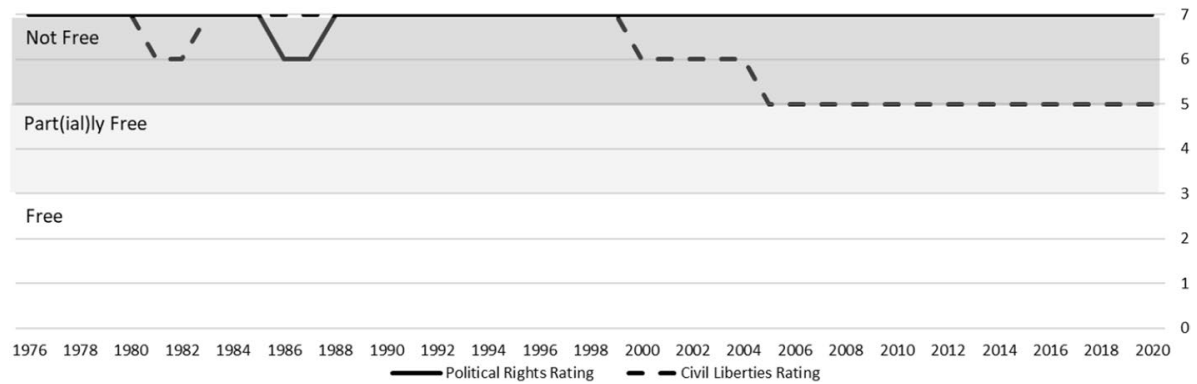

Fig. 2 Freedom house political rights and civil liberties for Vietnam (1976-2020). Source of data: https:// freedomhouse.org/. Note: Countries are categorised into one of three categories: 7.0 to 5.5 = 'Not Free'; 5.0 to $3.0=$ 'Part(ial)ly Free'; 2.5 to $1.0=$ 'Free'

economic freedom was repressed until 2006. In 2006, after a small increase of economic freedom, Vietnam's economic freedom has been classified as 'mostly unfree' until 2020.

Regarding political freedom, Freedom House's (2021) Global Freedom Index consistently classified Vietnam on political rights as "not free" (between 1976-2020. Civil liberties ratings edged up to "partially free" after 2005 (Freedom House, 2021) (Fig. 2).

Human Rights Watch (2019) cites examples of the Communist Party of Vietnam severely constraining civil and political rights. Independent media are prohibited and media channels strictly controlled, including the press, radio and television. Since 2019, when Vietnam's Cybersecurity Law came into effect, internet service providers must collect and store users' personal data and surrender it to the government upon request. It also reports providers must remove content within $24 \mathrm{~h}$ if instructed and that freedom of speech is suppressed. For example, police have allegedly used "excessive force" against public protests and punished government critics. Independent labor or human rights organizations and political associations are prohibited, suppressing freedom of association and 
assembly (Human Rights Watch, 2019). Reporters Without Borders (2020) rank Vietnam 175/180 in the World Press Freedom Index.

Overall, while economic freedom in Vietnam has fairly steadily improved since 1997, it remains ambiguous, with significant obstacles, including corruption and nepotism in most government sectors and judicial ineffectiveness (Heritage Foundation, 2020a). In 2020, The Heritage Foundation (2020a) ranked Vietnam the 105th-freest economy, slightly below world and regional averages. Political rights languish much lower.

Having considered trajectories of economic and political freedom, we next analyze the development of entrepreneurial activities in Vietnam.

\subsection{Entrepreneurship and innovation in Vietnam}

While political and economic freedoms in Vietnam are still weak and decidedly mixed, prosperity and social prosperity have risen sharply. In 1986, Vietnam ranked among the world's poorest countries (World Bank Group, 2020), and suffered from hyperinflation and economic stagnation and widespread poverty (Dollar \& Litvack, 1998). In the same year, major economic reforms occurred, such as allowing individual entrepreneurs to become active in the light industry, reducing government control, removing wage restrictions and allowing businesses to recruit worker as per their needs (Dana, 1994), thereby increasing labour freedom. Other important changes to increase economic freedom included the reduction of trade barriers, liberalisation of government controlled markets, and direct access for larger firms to international markets in 1987, removal of centralised price control, the introduction of rights to own land, attracting Foreign direct investment (FDI) by establishing Exporting processing zones (EPZs) in 1991; and encouragement of job creation through a reduction of the minimum wage for foreign entrepreneurs in 1992. As a result of these reforms, entrepreneurial activities subsequently flourished (Dana, 1994).

Vietnam is today a lower middle-income country, GDP per capita having increased 2.7 times between 2002-2018 alone, lifting over 45 million people out of poverty (World Bank Group, 2020). Thanks to the rapid economic growth within living memory of deprivation, and insofar as can be discerned within minimal freedom of speech, Vietnamese voice a comparatively high satisfaction with their government and optimism about their financial future for the next generation (The Pew Research Centre, 2014) despite minimal political freedom (Human Rights Watch, 2019).

Data from the General Statistics Office of Vietnam, depicted in Fig. 3, suggest an interesting relationship between economic freedom and the number of active firms in the Vietnamese economy. As mentioned above, economic freedom advanced steadily from the early 1990s-2006, changing from being classified as a 'repressed' to a 'mostly unfree' economy in 2006. After this transition the growth in the number of active non-state enterprises has accelerated. Thus, while absolute economic freedom in Vietnam remains consistently low, its rise since 1995 is commensurate with growth, which suggests higher levels of entrepreneurial activity. We infer that relative changes to economic freedom over time, rather than the absolute level of economic freedom or world rankings across countries are a major enabler of entrepreneurial activity and innovation leading to economic growth.

Supporting our inference, firm-level evidence shows an increase in entrepreneurial activities in Vietnam since the reforms, including more start-ups in technology intensive industries. While Vietnam has fewer start-ups than more developed nations like Korea (Nguyen et al., 2020), the number of firms has grown constantly since 2008. During this time, the percentage of IT firms stayed relatively stable, suggesting that high-tech firms 


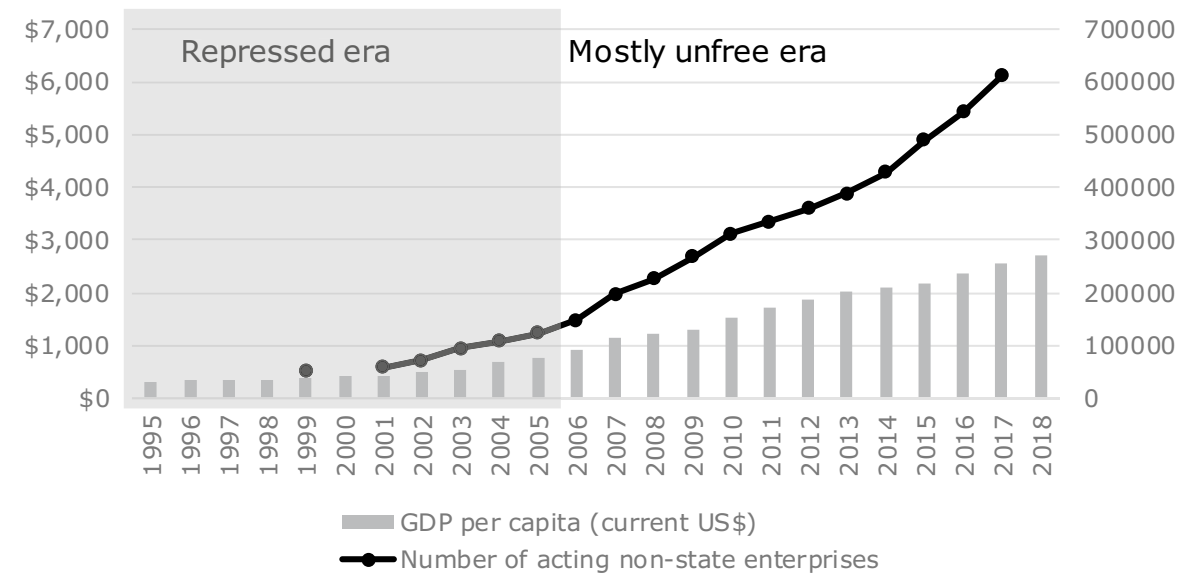

Fig. 3 Number of acting non-state enterprises and GDP per capita in Vietnam (1995-2018). Source: Data collated from Statistical Yearbooks of Vietnam. https://www.gso.gov.vn/en/?s=yearbook\&lang=en

must have steadily increased, which contributed to an increase in innovative entrepreneurship (based on White books, Vietnamese Government; Vietnam Economic Census data).

The upsurge in technology intensive industries has been enabled by start-ups exploiting newly adopted technologies (Santarelli \& Tran, 2017). Panel data covering 2005-2013 suggest furthermore persistent innovation among Micro-, small and medium-sized (MSM) businesses - not only critical for economic growth in general but also accounting for over $30 \%$ of Vietnam's GDP (Long, 2021).

Overall, we have demonstrated thriving entrepreneurship in Vietnam despite low and ambiguous absolute levels of political and economic freedom respectively. Rather, it was relative expansions in economic freedom that went hand-in-hand with entrepreneurship and economic growth. The next three sections explore mechanisms which might explain that observed associations regarding entrepreneurship.

\section{Mechanism supporting entrepreneurial activities in Vietnam}

\subsection{Advances in economic freedom, local entrepreneurs and a spirit of optimism}

Unlike many other fast-developing Asian economies, Vietnam's rising entrepreneurial activities can hardly be attributed to a centrally coordinated industrial policy or a "wellelaborated plan" (Ngo and Trako, 2018). While the shift from "a centrally planned to a market economy" was necessary for Vietnam to achieving entrepreneurship (Tran and Santarelli, 2013), growth and innovation (World Bank Group, 2020c), its policy framework has been criticized as weak and over-cautious (Yun, 2019), and we have noted the chronically poor government functioning (Freedom House, 2020b) and an apparent preference for FDI and big business (World Bank Group, 2019) over entrepreneurship. Government support for privately owned SMEs remains poor in many respects, and access to resources often challenging (Le and Nguyen, 2009). While the government initiated a national Entrepreneurship Program, entrepreneurship education is still fragmented and selective (Nguyen, 
Dinh, Luu and Choo, 2020). Santarelli and Tran (2013) report that schooling often does not prepare well for entrepreneurship and that formal business networks often under-serve entrepreneurs with regard to achieving their business goals, but they might be a member for political reasons.

Nonetheless, advances in economic freedom, especially regarding property rights, encouraged local Vietnamese to become entrepreneurs. Whereas outsiders, foreign investors among them, deemed early reforms post-1986 weak and slow, for the Vietnamese "who had lived in an environment where private property rights where not formally recognized until 1992, progress has appeared genuine enough" (Han and Baumgarte, 2000, p. 24). This reinforces that what matters for locals is not international rankings but improvements domestically over time. Small reforms expanded economic freedom and wedged through major obstacles to doing business; they bolstered confidence and raised optimism as Vietnamese entrepreneurs implicitly compared the post-reform settings with worse prereform days (Han and Baumgarte, 2000). Relative change pointed to Vietnam's positive arc of development. Vuong and Tran (2009) argue that ordinary Vietnamese have helped transform the economy by creating wealth and employment, shifting society's view of entrepreneurship as something undesirable towards embracing an entrepreneurial spirit.

More recently, Nguyen and Pham (2019) argue that the confidence of Vietnamese entrepreneurs has increased due to policy shifts and economic developments, and young Vietnamese entrepreneurs above all are eager, outward-looking and technology-savvy. Another survey $(\mathrm{N}=938)$ found Vietnamese 18-35 year olds materialistic, open-minded and enthusiastic with, notably, over $70 \%$ aspiring to create their own business (Nguyen and Phan, 2014), versus about $25 \%$ of all adults (based on data from the 2018 GEM report) (Nguyen et al., 2020). Similarly, The Pew Research Center (2014) found Vietnamese very optimistic about their children's future; $94 \%$ expecting their children will fare better financially than their parents did, making Vietnam among the most optimistic emerging nations.

These changes add up to a shift in cultural norms towards economic and technological openness, entrepreneurial spirit and ambition for financial independence. Overall, the case of Vietnam's changing cultural norms shows that small marginal improvements in economic freedom can have an important signalling effect for entrepreneurs, boosting optimism, entrepreneurial activity and ultimately prosperity, which in turn further spurs entrepreneurial activities through a virtuous circle. Entrepreneurship scholars recognize that both individual (Hmieleski and Baron, 2009) and collective optimism (Anglin, McKenny and Short, 2018) are conducive to heightened entrepreneurial activity and performance. Vietnamese entrepreneurs are embedded in a rosier context than their counterparts in societies with constant, even declining, wealth and static or shrinking economic freedom. After shifting toward a market economy small relative changes in economic freedom triggered a self-reinforcing process of optimism, entrepreneurship, looking forward and economic growth.

\subsection{Economic freedom, compression of development and individual aspirations}

Vietnam is a late developer economically (Ngo and Tarko, 2018). Traditionally, the economic growth of late developers in Asia has been understood to follow a set sequence (Akamatsu, 1961). Challenging this view recently, the literature on compression of development suggests that the stages of economic development can occur simultaneously, so "high and low development indicators" co-exist (Whittaker et al., 2010). For instance, in modern Asian economies, some sectors may focus on resource or labor-intensive 
activities, while others pursue innovative "high-tech Internet-based" offerings (Haworth, 2013). As an example of compressed development, Vietnam entered the textile-garment industry in the late 1970s to take advantage of its large low-skilled, low-paid labor force, once dominated by state-owned enterprises but progressively privatized (Ngo and Tarko, 2018). Meanwhile, Vietnam's ICT industry, which includes multinationals and globally competitive local firms, has boomed (Hirakawa and Nguyen, 2017).

Whittaker et al., (2020) point out that compressing development influences democratization. For now-developed countries, democratization and social citizenship followed industrialization, however, capitalism need not inexorably lead to democracy when there are no restraints on capital. Whittaker's team argue that the simultaneity of development in modern Asia means "class compromises are pursued before industrialization has created a strong material base for their stability" (p. 202). In this context the expectation that economic will bring political freedom is not a given; the link becomes more fragile, threatening the development of democracy (Whittaker et al., 2020). Indeed, it has been said that recent political reforms in China have an adaptive quality and are unlikely to foster democracy (Chai and Song, 2013). In fact, an "adaptive state" is a key characteristic of late developers as compressed economic development requires a "policy stretch". That is, amid fastchanging economic realities such as globalization, governments with policies fitted to low development indicators find themselves stretching to accommodate higher indicator development activities; they pursue certain outcomes more in reaction, adaptation and hindsight than by planning (Whittaker et al., 2010).

Implications of compressed development have been discussed for policy makers (Whittaker et al., 2010) and Multinational enterprises (MNEs) (Haworth, 2013), but less is known about what it might mean for entrepreneurship. Suehiro's (2008) study indicates entrepreneurs played a vital role in achieving "compressed industrialization" (p. 33) in East Asia, suggesting entrepreneurship is a key to understanding the compression of development. From Vietnam's entrepreneurial activity, we can observe that in the context of compressed development most high-tech firms still lack innovativeness and their competitiveness remains based on cost advantages, but simultaneously some aspirational success stories of individual innovative entrepreneurs (Klingler-Vidra and Wade, 2020). Competing based on cost advantages, such as low labor costs, indicates a relatively lower development indicator, where innovation indicates higher development.

Notably, aspirational successes have often occurred in ICT. Perhaps most famously, in 2014 one Nguyen Ha Dong's mobile app game Flappy Bird, became a global hit and an instant start-up legend at home. Anh-Minh Do, of Singapore-based global venture capitalists Vertex Ventures, calls that moment "monumental and magical," ${ }^{4}$ arguing it sparked an entrepreneurial spirit among Vietnamese, turning engineers and university students into entrepreneurs and igniting an industry.Product reviewer CNET corroborates this, saying the "Flappy Bird effect" unleashed a new wave of Vietnamese entrepreneurship. ${ }^{5}$ Other ICT successes included Mobivi, which now provides ecommerce services to factory workers; gaming and social networking corporation VNG; and Appota, a digital content provider. While all are exceptional cases rather than fruits of a "carefully calibrated startup ecosystem" (Sturgeon and Zylberberg, 2017), they nonetheless offer "models for emulation" (The World Bank 2016, p. 155).

\footnotetext{
${ }^{4}$ https://www.techinasia.com/vietnam-2015-light-at-the-end-of-the-tunnel.

5 https://www.cnet.com/news/why-flappy-bird-was-just-the-start-for-vietnams-startup-scene/..
} 
This points towards two important sub-mechanisms whereby compressed economic development may encourage entrepreneurship despite minimal political and lacklustre economic freedoms. First, entrepreneurial success is observed in relatively newer sectors adjacent to industries deemed important by the state. Specifically, local entrepreneurial successes sprang up in the software space adjacent to deliberately courted, newly arrived foreign hardware MNEs by government. Hence we argue entrepreneurs strategically pursued opportunities in a sector by accessing knowledge spillovers from large MNEs (Bhawe and Zhara, 2019). The state was more reactive in fostering entrepreneurship while focussing on areas populated by larger businesses. Ngoc and Ramstetter (2004) point out that in particular between mid-1990 and 2000, there was a rapid increase of foreign MNCs in Vietnam. Accommodatingly, it heightened economic freedom for local entrepreneurs to embrace new opportunities and develop markets that fell, at least initially, outside the scope of institutional settings which could be constraining for smaller firms.

That is, entrepreneurs flow into the niche before the government has had a chance to spot and regulate it. Succinctly put, entrepreneurship may thrive adjacent to key industries in new and emerging, fast-changing, developing areas of compressed developing economies where the adaptive state has not fully adapted yet so does not govern or constrain their freedom; and it may keep thriving provided the state leaves the activity alone or adapts to embrace it with enabling rather than constraining policy.

In the second sub-mechanism, local Vietnamese start-up successes served as inspirational role models (Klingler-Vidra and Wade, 2020) to change others' cultural-cognitive maps from focusing on necessity entrepreneurship, which often occurs in low-development areas, towards opportunities in the more innovative tech space that co-exist alongside them under compression. Even though these tech start-ups remain few, success an exception and barriers significant (The World Bank, 2016), all these early good news stories have inspired many domestic entrepreneurs to dream big and choose a more ambitious, independent career pathway.

\subsection{Improved economic freedom, returnee entrepreneurs and the Silicon Valley-style entrepreneurial template}

The Vietnamese diaspora, which the war accelerated, numbers some four million, and of those 58\% immigrated to North America according to Kumar and Vu (2014) (based on 2011 data from the Migrant Policy Institute). The Migration Policy Institute states in 2017 over 1.3million Vietnamese are based in the US, and in the period between 2012-2016, the Institute recorded a high concentration of Vietnamese in California (39 percent). ${ }^{6}$ Overseas Vietnamese, or Viet Kieu, especially US-based Vietnamese have enabled entrepreneurship at home via first remittances and later actual returnees, and along with both, business templates that supported entrepreneurship. The returnees exploited skills gaps, rising economic freedom within Vietnam and, as we shall describe, institutional voids. Partly because the remittances were channelled into investments that promoted growth Vietnamese view the US as a place where capitalism has born the fruits of investment and wealth creation (Small, 2019b), and, in a stunning statistic for an officially socialist country, 95\% of Vietnamese support a free market system, the highest among the 25 emerging market economies surveyed (Pew Research Center, 2014). Such has been the American boon to

\footnotetext{
${ }^{6}$ https://www.migrationpolicy.org/article/vietnamese-immigrants-united-states-5.
} 
Vietnam's growth that the US's free market system has partially guided and legitimized Vietnam's social and cultural transformation towards marketization.

Viet Kieu contributed remittances-'diaspora capital'. Recipients often ploughed this into cultivating skills, such as English language proficiency, or technical skills like, in one example, manicure training, to enable 'low-cost entry forms of entrepreneurship' in Vietnam (p. 4, Small, 2019a). Furthermore, a tide of returnee entrepreneurs brought resources and knowledge into the country to seize opportunities afforded by rising economic freedom. This followed the government opening up to trade and specifically relaxing limits on repatriation. Notably, after eleven years negotiating, Vietnam finally joined the WTO in 2007 (Than and Duong, 2009). As the case of China shows, accession to the WTO sends a pronounced signal of commitment to further export-led growth, capital inflows, and entrepreneurship (Fewsmith, 2001). Also, in 2000, Vietnam signed a bilateral trade agreement with the US, which came into effect the next year. These outward-oriented policies not only directly lifted economic freedom for Vietnamese entrepreneurs through enhanced market access but made Vietnamese at home and abroad anticipate that the government would further open their economy to international trade.

After immigrant numbers were relaxed, returnee entrepreneurs gained influence (Junge et al., 2015). Many were 1.5 or second generation Vietnamese Americans (Nguyen-Akbar, 2016). Of special relevance to ICT entrepreneurship, SarDesai (2005) estimated that about 10,000 Vietnamese Americans worked in Silicon Valley, at least fifteen as CEOs. Many had repatriated to set up their own IT companies, leveraging their knowledge and experience and creating jobs for an estimated 20,000 locals (SarDesai, 2005). Nguyen-Akbar (2016) also found repatriating Vietnamese entrepreneurs leveraged knowledge gained in America.

What stands out is that the US significantly outranks Vietnam in absolute levels of economic and political freedom. By Freedom House's broad classifications (2020a), politically the US is "free", scoring 86/100 on the Global Freedom Index, while Vietnam is "not free", scoring 20/100. And the 2020 Index of Economic Freedom from the Heritage Foundation (2020b) rates the US as "mostly free" (17/180 of countries ranked), and Vietnam as "mostly unfree" (105/180). Thus, returnee entrepreneurs perceived greater opportunity to fulfil their personal aspirations in Vietnam, than in their politically and economically freer host country where they had once pursued the "American dream" (Nguyen-Akbar, 2016). When picking the best context to pursue innovative opportunities, these returnee entrepreneurs seemed attracted by relative increases of freedom over time, within Vietnam, and in particular economic freedom, rather than being put off by the absolute levels of economic freedom-and the relative drop nationally across space between the US and Vietnam.

Looking at the achievements of these returnee entrepreneurs, there is some evidence that they have significantly contributed to the Vietnamese wider entrepreneurial ecosystem. Klingler-Vidra and Wade (2020), examined the efforts of the Vietnamese government to promote innovation in Vietnam through their Science and Technology (S\&T) policy to escape the middle-income trap. The authors argued that Vietnamese policy makers were inspired by Chinese success in policy setting that enabled technical capacity building, and believed they could emulate China's mission-oriented S\&T policies allowing them to transform Vietnam's innovation system. However, the Vietnamese policy makers were unsuccessful in achieving a fundamental transformation of the innovation capabilities resulted because their policies were less focused on technical capabilities compared to the Chinese S\&T policies. Instead what availed in Vietnam was government adopting a Silicon Valley Style entrepreneurial ecosystem which required only light-touch policies and modest 
financial resources, such as accelerator initiatives, start-up competitions and venture capital funding (Klingler-Vidra \& Wade, 2020).

That same Klingler-Vidra and Wade (2020) study reveals that returnee entrepreneurs were instrumental in shaping this broader "Silicon Valley-style entrepreneurial ecosystem". Given the correlation with a major influx of Silicon Valley and other US returnees, and growing official endorsement it appears ed that the policy settings of the United States have served as a template to shape Vietnamese policy. For instance, in May 2020 Prime Minister Phuc endorsed a merger of three districts of Ho Chi Minh City to create an innovation hub which will become "Vietnam's Silicon Valley. ${ }^{7}$ Importantly, this phenomenon is further enabled by Vietnam's institutional voids. To explain: the institutional framework in Vietnam as an emerging market is characterized by institutional voids: the legal and regulatory system is fragmented (Vuong, La, Vuong, Hoang, Ho, Ho and Nguyen, 2020) and incomplete (McAdam, Crowley and Harrison, 2019; Bruton, Ahlstrom and Li, 2010). In particular, limited access to critical business information, insufficient implementation of policies and regulation, and bribery (Nguyen and Pham, 2019) heighten uncertainties for doing business (Tran, 2019). However, while the lack of well-functioning formal institutions impedes entrepreneurial activities if, for instance, an entrepreneur needs to enforce a contract, institutional voids also open up distinct opportunities for returning Vietnamese entrepreneurs: the entrepreneurs get to fill them and shape the space to their own advantage, as institutional voids also provide a kind of unintended economic freedom in certain areas, due to the lack of regulation, there might be less restriction on enacting opportunities.

To exemplify this, Klingler-Vidra and Wade (2020) reported on a group of returnee Vietnamese American entrepreneurs, the "MIT Five", all graduates of the prestigious Massachusetts Institute of Technology, who repatriated and boosted the economy by emulating the Silicon Valley model. The five not only made significant input by advising the government into how to develop policies that could enable start-up activities, but also attracted high-tech MNCs to the market and helped form and grow successful start-ups. One of the five became Chief Technology Officer at one of Southeast Asia's first unicorns. In this vein, Thach Le Anh, a US-educated Vietnamese businesswoman now heading the accelerator Vietnam Silicon Valley, told CNET News: "I would like to bring the culture from Silicon Valley into Vietnam.... We want to bring the very different culture, very independent thinking and dreaming [to Vietnam]". ${ }^{8}$

In sum, highly educated returnee entrepreneurs brought back knowledge and skills acquired from developed countries to their emerging home country, facilitating economic growth and development (Demurger and $\mathrm{Xu}, 2011$ ). Institutional voids helped let them influence government officials, thereby formulating new institutions or reshaping old ones to their own and, it seems, Vietnam's, benefit based on US models. Improvements of economic freedom at home enabled them to return to Vietnam in the first place and then to set up businesses there and signalled to them that more commercial opportunities would follow.

\footnotetext{
${ }^{7}$ https://e.vnexpress.net/news/news/hcmc-pushes-ahead-with-vietnam-s-silicon-valley-plan-4103067.html.

${ }^{8}$ https://www.cnet.com/news/why-flappy-bird-was-just-the-start-for-vietnams-startup-scene/
} 


\section{Conclusion}

This paper has provided a reconciliation of the apparent entrepreneurship paradox posed by the context of Vietnam. If democracy, along with political and economic freedoms, are essential for entrepreneurship, as the extant literature in entrepreneurship has concluded, how is it that entrepreneurship has flourished, even with a paucity of democracy and economic and political freedoms? The answer provided in this paper is that in reaching this conclusion, the entrepreneurship literature has focused too narrowly on a limited context.

By contrast, in this paper, shifting the lens to the context provided by Vietnam leads to the conclusion that it is not just the extent but also changes in the extent of economic and political freedoms that matter in shaping entrepreneurial activity. In particular, the paper identifies how institutions in the particular context of Vietnam have been conducive to entrepreneurship by incrementally increasing the extent of economic freedoms. In particular, a blossoming of pro-entrepreneurship culture, compressed development and policies encouraging the diaspora to return to fill institutional voids have enabled entrepreneurship to thrive even in a context of limited economic and political freedoms.

These three cultural and institutional features specific to the context of Vietnam have ignited entrepreneurship. As this paper shows, despite lacklustre and low absolute levels of economic and political freedom, entrepreneurial activities have increased due to an emerging pro-entrepreneurship culture characterized by increased optimism reflecting a shift from necessity to opportunity entrepreneurship. The important role of the cultural atmosphere for entrepreneurial growth has been also pointed out by Lehmann and Seitz (2017). The increase of numbers of newly established businesses in Vietnam, including high-tech businesses, provides a compelling indicator that entrepreneurial activity and innovation for value creation has increased.

We contribute at a more granular level by analyzing the three underlying institutional and cultural features specific to the particular context of Vietnam that have enabled small increments in economic freedom to foster entrepreneurship. An important first mechanism is the emergence of a pro-entrepreneurship culture, which is reflected by an increase in optimism exhibited by entrepreneurs. As Huang (2008) found for Chinese entrepreneurs, our analysis shows private entrepreneurs, not government, forming their own assessments of the potential returns accruing from entrepreneurship, have been instrumental in making Vietnam a more entrepreneurial society. This entrepreneurial culture has blossomed despite barriers from severely restricted political freedoms.

The second underlying institutional aspect has been the compression of development. A defining characteristic of compressed development is the adaptive state, where certain government policies are often implemented more reactively and in hindsight than by planning (Whittaker et al., 2010). Our analysis shows that the policy-stretch created space for entrepreneurial activities. In particular, this paper finds that Vietnamese entrepreneurs have established successful businesses in new markets adjacent to key targeted industries. This enables them to access important spillovers from more developed industries; operating in adjacent industries that are not a government priority enables entrepreneurs to escape the heavy hand of policy interventions imposed by the government. This suggests that entrepreneurs identify niches based not only on their perception of existing players (Penrose, 1959), but also on the prospects for evading what otherwise would be strong and restrictive government interventions and control. Entrepreneurs operating in undemocratic contexts strive to avoid both direct large competitors and government control. They are attracted by adjacent opportunities characterised by institutional voids allowing them to create their 
own rules before the state adapts. Significantly, Vietnam as an adaptive state evinces scant intention to stretch further towards democracy than is necessary for economic adaptations. Therefore, the context of Vietnam does not support arguments and hypotheses positing that democracy is either a prerequisite to, or commensurate with, economic freedoms.

The third underlying institutional and cultural component enabling entrepreneurship in the context of Vietnam involves policies fostering the return of the diaspora. As a result, local start-up success stories transferred the cultural-cognitive maps from necessity entrepreneurship towards opportunity driven entrepreneurship in the high-tech sector. Although operating in institutional voids can dampen entrepreneurship through heightened uncertainty (Bruton, Ahlstrom, and Li, 2010) and transaction costs, our analysis suggests that improvements to economic freedom addressing some of the incomplete institutional framework can also breed opportunities. Specifically, we have shown how improvements in economic freedom have signalled that future opportunities will emerge in Vietnam and how this has lured back US-based Viet Kieu entrepreneurs. They perceive an opportunity to serve as a conduit for the spill over of knowledge and cultural maps (Silicon Valley-style entrepreneurship) to Vietnam to shape the specific context by filling key voids to achieve their aspirations. Our study therefore cautiously suggests that the extent to which voids are an opportunity and are realized by entrepreneurs depends on the general direction of the evolution of economic freedoms.

These underlying cultural and institutional conditions specific to the particular context have enabled Vietnam to incrementally enhance specific key freedoms: property rights; basic reorientation to market economy; trade and immigration. It seems Vietnam has loosened government's political hold just enough to raise these, which has ignited entrepreneurship and ultimately triggered remarkable growth and prosperity.

Much has been made about the importance of knowledge spillovers as a catalyst for entrepreneurship (Audretsch and Keilbach, 2004). However, the findings of this paper suggest that a different type of externality, which could be characterized as constituted political spillovers, may matter in at least two important ways. The first is through the mobility of entrepreneurs across geographic and jurisdictional boundaries. As is the case in Vietnam, entrepreneurial activity responding to institutions and policies in one jurisdictional context, such as Silicon Valley, can spill over through entrepreneurial mobility for a manifestation in a very different jurisdictional context.

The second way is through the actual diffusion of policy priorities and goals. Observing the benefits in terms of economic performance resulting from a shift towards an entrepreneurial driven society can serve as a catalyst for prioritizing policies to spur entrepreneurship in a very different institutional and political context, such as Vietnam. Even though the adaption may be unique to the particular context, the priority of policies and institutions conducive to entrepreneurship spills over from the first movers to subsequent adapters, which in this case is Vietnam.

\subsection{Generalizability, limitations and future research}

Similar to others (Anderson and Obeng, 2017; Siggelkow, 2007), we draw on a single case. The aim of this paper is to illustrate mechanisms that can explain how entrepreneurship might strive without democracy, rather than to generalise to a wider population. Nonetheless, the Vietnamese entrepreneurship paradox invites analogies with other emerging market contexts, in particular China, which similarly fuses capitalist economics with 
Communist politics. The two nations' combined success in selectively decoupling democracy and political freedoms from economic freedoms and entrepreneurship amongst 1.5 billion people has been significant. Future research could test whether relative changes to political and economic freedoms affect entrepreneurship using cross-country data, in particular from emerging markets with low absolute level of freedoms but high relative changes in economic and political freedoms.

Only time and future research can tell how long Vietnam's entrepreneurship progress will be sustained, and future research could also gain interesting insights into whether economic freedoms will have to keep expanding, as our conclusions suggest, and whether the rising class of entrepreneurs will call for political freedoms, especially returnee entrepreneurs.

Some principles suggest themselves for entrepreneurship-focused policymakers and practitioners. Policymakers pursuing entrepreneurship should try to champion economic freedoms, especially types like property rights, which we have tentatively identified as central. Vietnam's and other governments should watch evolving institutional voids and policy gaps before deciding how, and whether, to adapt and to fill them, in order to sustain the entrepreneurial spirit that leads to economic growth.

\section{References}

Akamatsu, K. (1961). A theory of unbalanced growth in the world economy. Weltwirtschaftliches Archiv, $86,196-217$.

Anderson, A. R., \& Obeng, B. A. (2017). Enterprise as socially situated in a rural poor fishing community. Journal of Rural Studies, 49, 23-31.

Anglin, A. H., McKenny, A. F., \& Short, J. C. (2018). The impact of collective optimism on new venture creation and growth: a social contagion perspective. Entrepreneurship Theory and Practice, 42(3), $390-425$.

Audretsch, D. B., Keilbach, M. (2004). Does entrepreneurship capital matter? Entrepreneurship Theory and Practice, 28(5), 419-430.

Audretsch, D. B., \& Moog, P. (2020). Democracy and entrepreneurship. Entrepreneurship Theory and Practice. https://doi.org/10.1177/1042258720943307.

Bennett, D. L. (2021). Local economic freedom and creative destruction in America. Small Business Economics, 56(1), 333-353.

Berggren, N. (2003). The benefits of economic freedom: a survey. The Independent Review, 8, 193-211.

Bhawe, N., \& Zahra, S. A. (2019). Inducing heterogeneity in local entrepreneurial ecosystems: The role of MNEs. Small Business Economics, 52(2), 437-454.

Bjørnskov, C., \& Foss, N. (2008). Economic freedom and entrepreneurial activity: some cross-country evidence. Public Choice, 134, 307-328.

Bradley, S. W., \& Klein, P. (2016). Institutions, economic freedom, and entrepreneurship: the contribution of management scholarship. Academy of Management Perspectives, 30(3), 211-221.

Bruton, G., Sutter, C., \& Lenz, A. K. (2021). Economic inequality-Is entrepreneurship the cause or the solution? A review and research agenda for emerging economies. Journal of Business Venturing, 36(3), https://doi.org/10.1016/j.jbusvent.2021.106095.

Bruton, G. D., Ahlstrom, D., \& Li, H. L. (2010). Institutional theory and entrepreneurship: where are we now and where do we need to move in the future? Entrepreneurship Theory and Practice, 34(3), 421-440.

Chai, H., \& Song, X. (2013). The adaptive state-understanding political reform in China. Policy Studies, 34(1), 73-88.

Clark, J. R., \& Lee, D. R. (2006). Freedom, entrepreneurship and economic progress. The Journal of Entrepreneurship, 15(1), 1-17.

Dana, L. P. (1994). A Marxist mini-dragon? Entrepreneurship in today's Vietnam. Journal of Small Business Management, 32(2), 95-102. 
Démurger, S., \& Xu, H. (2011). Return migrants: the rise of new entrepreneurs in rural China. World Development, 39(10), 1847-1861.

Dheer, R. J. (2017). Cross-national differences in entrepreneurial activity: role of culture and institutional factors. Small Business Economics, 48(4), 813-842.

Dollar, D., \& Litvack, J. (Eds.). (1998). Household welfare and Vietnam's transition. The World Bank.

The Economist. (2016). Vietnam's Economy: The Other Asian Tiger. 420(9001), 6th August 2016.

Fewsmith, J. (2001). The political and social implications of China's accession to the WTO. The China Quarterly, 167, 573-591.

Friedman, M. (1962). Capitalism and Freedom. University of Chicago Press.

Freedom House. (2021). Publication Archives. https://freedomhouse.org/reports/publication archives

Freedom House. (2020a). Countries and Territories - Global Freedom Scores. https://freedomhouse.org/ countries/freedom-world/scores

Freedom House. (2020b). Vietnam. Freedom in the World 2020. https://freedomhouse.org/country/vietnam/ freedom-world/2020

Gasparin, M., \& Quinn, M. (2021). Designing regional innovation systems in transitional e economies: a creative ecosystem approach. Growth and Change, 52, 621-640.

Global Innovation Index (2019). GLOBAL INNOVATION INDEX 2019, Creating Healthy Lives-The Future of Medical Innovation, 12th edition. https://www.wipo.int/global_innovation_index/en/ 2019/index.html.

Gohmann, S. F., Hobbs, B. K., \& McCrickard, M. (2008). Economic freedom and service industry growth in the United States. Entrepreneurship Theory and Practice, 32(5), 855-874.

Han, V. X., \& Baumgarte, R. (2000). Economic reform, private sector development, and the business environment in Viet Nam. Comparative Economic Studies, 42(3), 1-30.

Heritage Foundation (2020a). 2020 Index of Economic Freedom. Vietnam. https://www.heritage.org/ index/country/vietnam.

Heritage Foundation (2020b). 2020 Index of Economic Freedom. https://www.heritage.org/index/ranki ng.

Heritage Foundation. (2021). 2021 Index of Economic Freedom. https://www.heritage.org/index/visualize? cnts $=$ vietnam \&src $=$ country.

Herrera-Echeverri, H., Haar, J., \& Estévez-Bretón, J. B. (2014). Foreign direct investment, institutional quality, economic freedom and entrepreneurship in emerging markets. Journal of Business Research, 67(9), 1921-1932.

Hewlett, S. A. (1979). Human rights and economic realities: trade-offs in historical perspective. Political Science Quarterly, 94(3), 453-473.

Hirakawa, H., Nguyen, T. B. H. (2017). The development of ICT-based service industries in Vietnam and Japanese firms' offshoring. In Innovative ICT Industrial Architecture in East Asia (pp. 115140). Springer, Tokyo.

Huang, Y. (2008). Capitalism with Chinese characteristics: Entrepreneurship and the state. Cambridge University Press.

Human Rights Watch (2019). Vietnam Events of 2018. https://www.hrw.org/worldreport/2019/countrychapters/vietnam\#.

Hmieleski, K. M., \& Baron, R. A. (2009). Entrepreneurs' optimism and new venture performance: a social cognitive perspective. Academy of Management Journal, 52(3), 473-488.

Junge, V., Diez, J. R., \& Schätzl, L. (2015). Determinants and consequences of internal return migration in Thailand and Vietnam. World Development, 71, 94-106.

Kuckertz, A., Berger, E. S., \& Mpeqa, A. (2016). The more the merrier? Economic freedom and entrepreneurial activity. Journal of Business Research, 69(4), 1288-1293.

Kumar, R. R., \& Vu, H. T. T. (2014). Exploring the nexus between ICT, remittances and economic growth: a study of Vietnam. Journal of Southeast Asian Economies, 31(1), 104-120.

Klingler-Vidra, R., \& Wade, R. (2020). Science and technology policies and the middle income trap: lessons from Vietnam. The Journal of Development Studies, 56(4), 717-731.

Le, N. T. B., \& Nguyen, T. V. (2009). The impact of networking on bank financing: the case of small and medium-sized enterprises in Vietnam. Entrepreneurship Theory andPractice, 33(4), 867-887.

Lehmann, E. E., \& Seitz, N. (2017). Freedom and innovation: a country and state level analysis. The Journal of Technology Transfer, 42(5), 1009-1029.

Li, H., \& Xu, Z. (2007). Economic convergence in seven Asian economies. Review of Development Economics, 11(3), 531-549.

Long, T. Q. (2021). Is innovation activity persistent among small firms in developing countries? Evidence from Vietnam. Journal of the Asia Pacific Economy, 26(1), 140-157. https://doi.org/10.1080/13547 860.2020 .1724755 . 
McAdam, M., Crowley, C., \& Harrison, R. T. (2019). "To boldly go where no [man] has gone before"Institutional voids and the development of women's digital entrepreneurship. Technological Forecasting and Social Change, 146, 912-922. https://doi.org/10.1016/j.techfore.2018.07.051.

McMullen, J. S., Bagby, D. R., \& Palich, L. E. (2008). Economic freedom and the motivation to engage in entrepreneurial action. Entrepreneurship Theory and Practice, 32(5), 875-895.

Ngoc, P. M., \& Ramstetter, E. D. (2004). Foreign multinationals and local firms in Vietnam's economic transition. Asian Economic Journal, 18(4), 371-404.

Haworth, N. (2013). Compressed development: global value chains, multinationa enterprises and human resource development in 21st century Asia. Journal of WorldBusiness, 48(2), 251-259.

Ngo, C., \& Tarko, V. (2018). Economic development in a rent-seeking society: socialism, state capitalism and crony capitalism in Vietnam. Canadian Journal of Development Studies/revue Canadienne D'études Du Développement, 39(4), 481-499.

Nguyen-Akbar, M. (2016). Finding the American Dream Abroad? Narratives of Return Among 1.5 and Second Generation Vietnamese American Skilled Migrants in Vietnam. Journal of Vietnamese Studies, 11(2), 96-121. https://doi.org/10.1525/jvs.2016.11.2.96.

Nguyen, P. M., Dinh, V. T., Luu, T.-M.-N., \& Choo, Y. (2020). Sociological and theory of planned behaviour approach to understanding entrepreneurship: comparison of Vietnam and South Korea. Cogent Business \& Management, 7(1), 1-21.

Nguyen, M., \& Phan, A. (2014). Entrepreneurial traits and motivations of the youth - an empirical study in Hoh Chi Minh City - Vietnam. International Journal of Business and Social Science, 5(1), 53-62.

Nguyen, H. T. T., \& Pham, H. T. S. (2019). An Exploration of Vietnamese Entrepreneurs. In J. Scott (Ed.), Gibb, J (pp. 266-285). A Contextualised Approach, Edward Elgar Publishing.

Nguyen, Q. A., Mort, G. S., \& D'Souza, C. (2015). Vietnam in transition: SMEs and the necessitating environment for entrepreneurship development. Entrepreneurship \& Regional Development, 27(34), 154-180.

Penrose, E. T. (1959). The Theory of the Growth of the Firm. Oxford University Press.

Santarelli, E., \& Tran, H. T. (2017). Young innovative companies: are they high performers in transition economies? Evidence for Vietnam. The Journal of Technology Transfer, 42(5), 1052-1076.

Santarelli, E., \& Tran, H. T. (2013). The interplay of human and social capital in shaping entrepreneurial performance: the case of Vietnam. Small Business Economics, 40(2), 435-458.

Santarelli, E., \& Tran, H. T. (2012). Growth of incumbent firms and entrepreneurship in Vietnam. Growth and Change: A Journal of Urban and Regional Policy, 43(4), 638-666.

Saunoris, J. W., \& Sajny, A. (2017). Entrepreneurship and economic freedom: cross-country evidence from formal and informal sectors. Entrepreneurship \& Regional Development, 29(3-4), 292-316.

SarDesai, D. R. (2005). Vietnam: Past and present. Westview Press.

Siggelkow, N. (2007). Persuasion with case studies. Academy of Management Journal, 50(1), $20-24$.

Small (2019a) Remitting Desire: Trans-Pacific Migration, Returns and Imaginaries in Vietnam. ISEAS Yusof Ishak Institute, Issue 2019, No. 56.

Small, I. V. (2019b). Currencies of Imagination. Cornell University Press. https://www.cornellpress. cornell.edu/book/9781501716881/currencies-of-imagination/ .

Suehiro, A. (2008). Catch-up industrialization: The trajectory and prospects of East Asian economies. NUS Press.

Sturgeon, T., \& Zylberberg, E. (2017). Vietnam's Evolving Role in ICT Global Value Chains.

Thanh, V. T., \& Duong, N. A. (2009). Vietnam after two years of WTO accession: what lessons can be learnt? ASEAN Economic Bulletin, 26(1), 115-135.

The Pew Research Center (2014). Emerging and Developing Economies Much More Optimistic than Rich Countries about the Future. https://www.pewresearch.org/global/2014/10/09/emerging-anddevelopingeconomies-much-more-optimistic-than-rich-countries-about-the-future/.

The World Bank Group (2014). Enterprises Surveys: what businesses experience. Vietnam. https://www. enterprisesurveys.org/en/data/exploreeconomies/2015/vietnam.

The World Bank Group (2015). Vietnam 2015 Country Profile. https:/www.enterprisesurveys.org/conte nt/dam/enterprisesurveys/documents/country/Vietnam-2015.pdf

The World Bank Group (2016). Vietnam 2035: Toward Prosperity, Creativity, Equity, and Democracy.http://documents1.worldbank.org/curated/en/996421479825859721/pdf/103435-v2PUBLIC.pdf.

The World Bank Group (2017) Country Highlights. Vietnam 2015. https://www.enterprisesurveys.org/ content/dam/enterprisesurveys/documents/country/highlights/Vietnam-2015.pdf.

The World Bank Group (2019). Vietnam's Economy Expanded by 6.8 Percent in 2019 but Reforms are Needed to Unleash the Potential of Capital Markets. December 2019. https://www.worldbank.org/ 
en/news/press-release/2019/12/17/vietnams-economy-expanded-by-68-percent-in-2019-but-refor ms-are-needed-to-unleash-the-potential-of-capital-markets.

The World Bank Group (2021a). Doing Business. Measuring Business regulations. https://www.doing business.org/en/rankings.

The World Bank Group (2020b) Enterprises Surveys: What businesses experience. Vietnam. https:// www.enterprisesurveys.org/en/data/exploreeconomies/2015/vietnam\#corruption.

The World Bank Group (2020c). The World Bank in Vietnam. https:/www.worldbank.org/en/country/ vietnam/overview.

Tran, H. T. (2019). Institutional quality and market selection in the transition to market economy. Journal of Business Venturing, 34(5), 105890.

Tran, H. T., \& Santarelli, E. (2014). Capital constraints and the performance of entrepreneurial firms in Vietnam. Industrial and Corporate Change, 23(3), 827-864.

Tsai, K. S. (2005). Capitalists without a class: political diversity among private entrepreneurs in China. Comparative Political Studies, 38(9), 1130-1158.

Tsai, K. S. (2007). Capitalism without democracy: the private sector in contemporary China. Cornell University Press.

Vuong, Q. H., La, V. P., Vuong, T. T., Hoang, P. H., Ho, M. T., \& Ho, M. T. (2020). Multi- faceted insights of entrepreneurship facing a fast-growing economy: A literature review. Open Economics, $3(1), 25-41$.

Vuong, Q. H., \& Tran, T. D. (2009). The cultural dimensions of the Vietnamese private entrepreneurship. The IUP Journal of Entrepreneurship and Development, 6(3-4), 54-78.

Whittaker, D. H., Zhu, T., Sturgeon, T., Tsai, M. H., \& Okita, T. (2010). Compressed development. Studies in Comparative International Development, 45(4), 439-467.

Whittaker, D. H., Sturgeon, T., Okita, T., \& Zhu, T. (2020). Compressed Development: Time and Timing in Economic and Social Development. Oxford University Press.

Reporters Without Borders. (2020). World Press Freedom Index. https://rsf.org/en/ranking/2020.

$\mathrm{Xu}, \mathrm{Z}$., \& Li, H. (2008). Political freedom, economic freedom, and income convergence: do stages of economic development matter? Public Choice, 135(3-4), 183-205.

Yun, M. (2019). Technological capability of MSMEs and implications for innovation policy: a case study of Vietnam. KIEP No. APEC Study Series, 19-02.

Publisher's Note Springer Nature remains neutral with regard to jurisdictional claims in published maps and institutional affiliations. 